DOI: https://doi.org/10.34069/AI/2022.49.01.18 How to Cite:

Mishchenko, M., Lukianets-Shakhova, V., Rostetska, S., \& Shvets, S. (2022). Constitutional and legal framework for gender equality in Ukraine and world countries. Amazonia Investiga, 11(49), 165-174. https://doi.org/10.34069/AI/2022.49.01.18

\title{
Constitutional and legal framework for gender equality in Ukraine and world countries
}

\section{Конституційно-правові засади гендерної рівності в Україні та зарубіжних країнах}

Received: November 1, 2021

Accepted: December 26, 2021

\author{
Written by: \\ Maksym Mishchenko ${ }^{69}$ \\ https://orcid.org/0000-0003-3107-0426 \\ Valentyna Lukianets-Shakhova ${ }^{70}$ \\ https://orcid.org/0000-0003-2397-613X \\ Svitlana Rostetska ${ }^{71}$ \\ https://orcid.org/0000-0002-3836-8922 \\ Svitlana Shvets ${ }^{72}$ \\ https://orcid.org/0000-0002-2886-1537
}

Abstract

This research aims at a comparative analysis of the constitutional and legal foundations of gender equality in Ukraine and other countries, as well as the study of the constitutional and legal provision influence on the indicator of Global Gender Gap Index. The research uses the method of analysis, synthesis, comparison, generalization, systematization, cluster analysis. Research results on the influence of constitutional and legal provision on the Global Gender Gap Index, there are three groups among the EU countries: countries with a higher level of gender equality (Global Gender Gap Index between 0.784-0.861: Ireland, Finland, France, Germany, Spain, and Sweden); countries with a more or less high level of gender equality (Global Gender Gap Index between 0.762-0.778: Latvia, Netherlands, and Portugal), and countries with an average level of gender equality (Global Gender Gap Index between 0.688 and 0.726: Greece, Cyprus, Luxembourg, Malta, Romania, Slovakia, Hungary, Czech Republic). The first group of countries has a more advanced constitutional and legal provision for gender equality. In the second group - the principles of constitutional and legal provision for gender equality are not fully implemented. In the third group - the constitutional and legal provision

\section{Анотація}

Метою дослідження є компаративний аналіз конституційно-правових засад гендерної рівності в Україні та інших країнах, а також вивчення впливу конституційно-правового забезпечення на показник глобального індексу гендерного розриву. У дослідженні застосовується метод аналізу, синтезу, порівняння, узагальнення, систематизації, кластерний аналіз. Результати дослідження впливу конституційно-правового забезпечення на показник Глобального індексу гендерного розриву виділили серед країн ЄС три групи: країни із більш високим рівнем забезпечення гендерної рівності (Глобальний індекс гендерного розриву 0,784-0,861: Ірландія, Іспанія, Німеччина, Фінляндія, Франція та Швеція), країни із відносно високим рівнем (Глобальний індекс гендерного розриву 0,762-0,778: Латвія, Нідерланди, Португалія) та країни із середнім рівнем (Глобальний індекс гендерного розриву у межах 0,688 - 0,726: Греція, Кіпр, Люксембург, Мальта, Румунія, Словаччина, Угорщина та Чехія). Для країн першої групи характерне досконаліше правове забезпечення гендерної рівності; у другій групі принципи забезпечення конституційноправових засад гендерної рівності

\footnotetext{
${ }^{69} \mathrm{PhD}$ student, Constitutional law and human rights department, National Academy of Internal Affairs, Ukraine.

${ }^{70}$ Candidate of Law Science, Associate Professor, professor of constitutional law and human rights department, Constitutional law and human rights department, National Academy of Internal Affairs, Ukraine.

${ }^{71}$ Doctor of Political Science, Associate Professor, Department of Political Science and Law, South Ukrainian National Pedagogical University named after K.D. Ushynsky, Ukraine.

${ }^{72}$ Candidate of political science, Assistant of the Political Science and Law Department, Faculty of Social Sciences and Humanities, Political and Law Department, South Ukrainian National Pedagogical University named after K.D. Ushynsky, Ukraine.
} 
needs reviewing and improvement. Ukraine characterized by gender inequality, violence against women, low level of the legal protection of women, limitation of their access to participation in public, political and economic life.

Keywords: Constitutional and legal framework, gender equality, Global Gender Gap Index, gender policy.

\section{Introduction}

Ensuring equal rights of men and women under the increasing globalization, internationalization, and mega-regionalization processes is one of the important aspects of law-making activities of the state, as well as an indicator of the effective functioning of society. The current state of socioeconomic development testifies about the special significance of this problem for Ukraine since the society is still not fully aware of its existence. Even though the Constitution of Ukraine (1996) regulates the democratic principles of state development, guarantees the freedom of personality, general political and legal principles of gender equality, the life realities prove the presence of the gender inequality problem and its special acuteness both in society and in different institutions.

The desire to integrate into the world economic, legal space and the chosen course of building European democratic institutions, confirms the need to affirm the gender equality value, to prevent gender discrimination, and to ensure equal rights of men and women to participate in decision-making, to realize opportunities and to combine family and professional responsibilities. The problem of researching the constitutional and legal foundations and state mechanisms to ensure gender equality in Ukraine and foreign countries, therefore, is extremely relevant.

This research aims the comparative analysis of the constitutional and legal framework of gender equality in Ukraine and other countries, as well as the study of the constitutional and legal provisions' impact on the Global Gender Gap Index.

\section{Literature review}

The proclamation of all people's equality before the law based on democracy, granting women реалізовуються не в повній мірі; у третій конституційно-правове забезпечення потребує перегляду та удосконалення. Для України характерна присутність гендерної нерівності, вчинення насильних дій щодо жінок, низький рівень правового захисту жінок, обмеження їх доступу до участі в суспільно-політичному та економічному житті.

Ключові слова: конституційно-правове забезпечення, гендерна рівність, Глобальний індекс гендерного розриву, гендерна політика.

equal rights and opportunities for self-realization on a level with men in the process of establishing social society is defined by gender equality. The democratic changes that have taken place in Europe have not been able to stop the spread of discrimination based on gender. For quite a long time, the national and international law-making practice has focused on the creation of new documents, which normative and legal support was aimed at the protection of human and civil rights. However, when it comes to gender equality, the problem is not limited to women's rights. In this context, the focus is on the equality of men and women in their own lives and society.

In this light, the Council of Europe, by adopting the Gender Equality Strategy for 2018-2023 (Council of Europe, 2018), has attempted to standardize European human rights and rule of law legislation based on the introduction of rights and opportunities for men and women. According to this normative legal act, gender equality implies equal rights, equal importance, opportunities, responsibilities of men, women, boys, and girls, as well as their equal participation in all spheres of public and private life, equal access to resources, and rights.

It should be noted that the problem of gender equality in Ukraine is urgent, and its solution is aimed at achieving parity of women and men in all spheres of political, socio-economic life, society and at applying special measures to eliminate the opportunities' imbalance. The Law of Ukraine (Law of Ukraine № 2866-IV 2005) "On ensuring equal rights and opportunities for women and men" regulates the main directions of state policy on ensuring equal rights and opportunities for women and men, defines the mechanism for ensuring equal rights and opportunities, and also establishes the legal framework for preventing and counteracting 


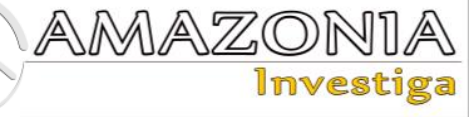

gender-based violence and liability for violation of legislation in this sphere. In addition, the law defines a list of government bodies authorized to perform the functions of implementing gender policy.

The regulatory support of gender equality in Ukraine is at a sufficiently high level, as evidenced by some legislative and regulatory legal acts; harmonized with the norms of international law. In addition, the Constitution of Ukraine establishes the equal legal status of men and women, defines equal opportunities for its realization based on equal participation in public life. In particular, Article 21 protects the equality of all people in their dignity and rights, inalienable and inviolable. Article 24 enshrines the equality of rights of women and men before the law, ensures the provision of equal constitutional rights, freedoms, and opportunities in social, political, and cultural activities, education and training, choice of place of work and its payment, establishing pension benefits, as well as creating conditions, under which women can combine work and motherhood It should be mentioned that in most of the countries of the former Soviet Union women are much less incentivized to work than men. Women have much less incentive to invest in their training and self-development, as their careers are intermittent and last for a shorter time.

To prevent and counteract discrimination, the Law of Ukraine (Law of Ukraine № 5207-VI, 2012) "On the Principles of Preventing and Combating Discrimination in Ukraine" was adopted, an organizational and legal mechanism for preventing and counteracting discrimination, in particular, based on gender and administrative, civil and criminal liability for violation of the requirements of this law was determined, while domestic violence was recognized as a criminal offense. Fritsky and Romanyuk (2017) believe that violence against women is one of the unresolved problems that require immediate legal intervention by the state, and the responsibility for committing such crimes, according to the Criminal Code of Ukraine № 2341-III (2001), is too liberal.

Among the main obstacles to gender equality by The Concept of the State social program to ensure equal rights and opportunities for women and men until 2021 (Order № 229-r, 2017) are identified the discrimination and the existence of significant structural barriers in many areas that limit women's ability to enjoy their basic rights. In particular, progress in women's political participation, access to justice, and the elimination of gender stereotypes and sexism have been too slow. In addition, violence against women and economic dependence on men is not the only important problem at this stage. The results of retrospective analysis of gender equality suggest that by the $\mathrm{XX}$ century, the legislation of most countries subordinated women to men, and the presence of women in public life was excluded (Mohanty, 1988). At this stage, men were the greatest obstacle to women's advancement in politics and economics (Razavi \& Miller, 1995). At the same time, any financial independence of women and their right to dispose of property were denied. Only at the end of the XX century in Europe, the concept of gender development of society begins to be popularized, and women began to get equal rights with men. During this period, the idea of gender equality was documented in the UN program, which proclaimed the ability of women to contribute to the economic development of the world community (Hazel, 2000).

In European Union countries, legal systems took gender differences into account, giving women and men equal social status. The development of law-making in such countries is based on the principle of gender-developed legislation. The main disadvantage of research on the constitutional and legal foundations of gender equality in the European Union countries is the lack of their comprehensive nature and the direction into separate areas. However, the positive experience of gender equality for Ukraine is interesting and useful because a comparison of the norms of the Constitution of Ukraine (1996) with international acts shows their sufficient consistency and, in some cases, actually repeats their content.

\section{Methodology}

The study uses the method of economic analysis, synthesis in the study of theoretical and methodological foundations of a particular problem; the method of comparison in the analysis and evaluation of indicators; cluster analysis in grouping the countries of Europe and Ukraine on the indicator of the global gender gap index; method of generalization and systematization in forming hypotheses and conclusions. Ukraine and the EU countries were chosen to conduct the research.

The information database of the study is based on the reports for 2017-2020: The Global Gender Gap Report on the Global Gender Gap Index indicators and its sub-indices. 


\section{Results and Discussion}

Since gender inequality is one of the manifestations of a population's socio-economic deformation, its empirical assessment becomes important. International organizations, together with regional institutions, annually calculate the Global Gender Gap Index, which tracks the achievement of gender equality according to such indicators as (1) economic participation and opportunity; (2) educational attainment; (3) access to health care; and (4) political empowerment. Based on the results of these studies, it is possible to comprehensively characterize the state of gender equality in a particular country.

Using the data of the Global Gender Gap Report during the period 2017-2020, we will calculate the dynamics of the Global Gender Gap Index in Ukraine (Figure 1), which assesses the country's ability to distribute its resources and opportunities among men and women. According to the analysis results and indicators values, the most favorable situation for gender equality was in 2019 (its value is 0,721). There were no stable trends during the analyzed period, and fluctuations of the indicator indicate the presence of gender inequality in the country.

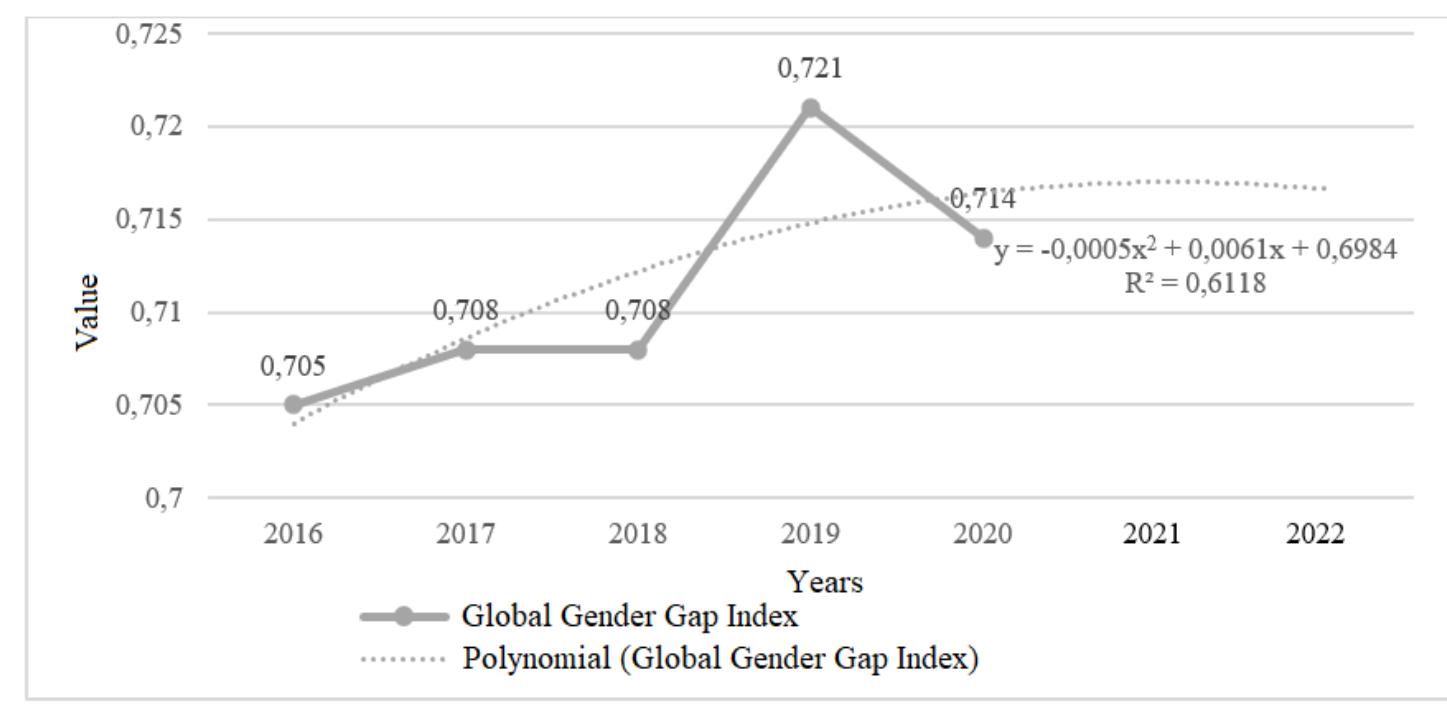

Figure 1. Dynamics of the Global Gender Gap Index in Ukraine, 2016-2022 (2021-2022 forecast estimates)

Source: Calculations based on The Global Gender Gap Report -2017, The Global Gender Gap Report 2018, The Global Gender Gap Report - 2019, The Global Gender Gap Report -2020.

For more detailed research, we suggest deepening the calculations and tracing the change of sub-indices of the Global Gender Gap Index in Ukraine for the same period (Figure 2). The obtained data shows that during the period, under consideration the situation was unambiguously stable concerning such indicators as the level of education and access to the health care system. There was no unambiguous positive trend for economic participation and opportunity, and the value of the indicator ranged from 0.736 in 2016 to 0.747 in 2017 and declined to 0.732 between 2019 and 2020. At the same time, the value of the policy empowerment sub-index was at 0.107 in 2016 and 2017 and increased significantly by 0.064 in 2019 . However, this index went down to the 0.147 mark during 2020. In general, it can be argued that the most optimal are the indicators of access to education for women and men, as evidenced by the value of the corresponding sub-index -1 . The levels of rights and opportunities received by both sexes in Ukraine in obtaining access to the health care system and rights to medical care. 


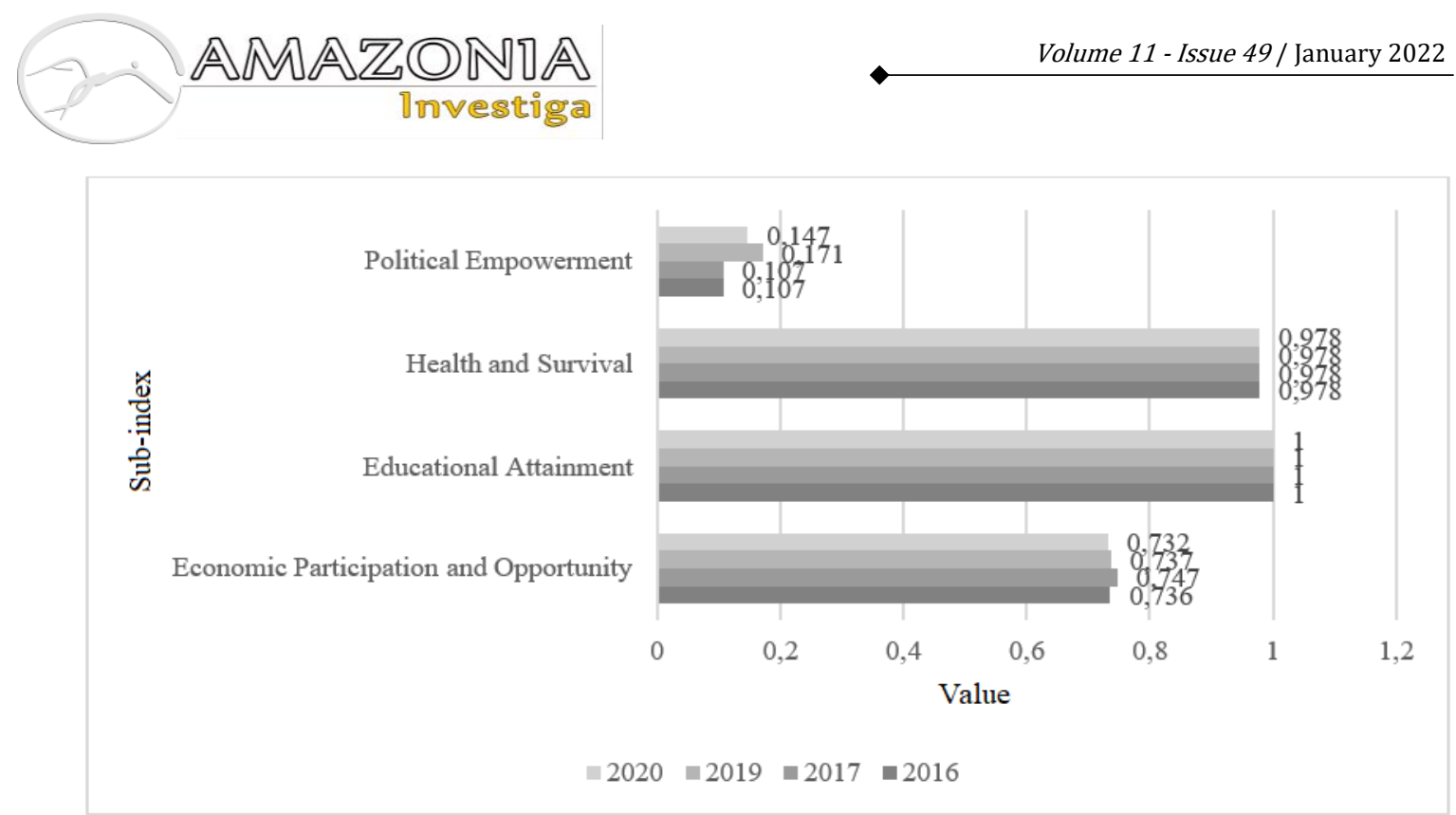

Figure 2. Dynamics of the Global Gender Gap Index sub-indices in Ukraine, 2016-2017 and 2019-2020 Source: Calculations based on The Global Gender Gap Report - 2017, The Global Gender Gap Report 2018, The Global Gender Gap Report -2019, The Global Gender Gap Report - 2020.

Concerning women's economic participation and opportunities for financial independence, there are tangible distortions, confirming a downward trend.

The most critical situation is about the empowerment of women in politics. The results suggest a hypothesis that the constitutional and legal mechanism for ensuring gender equality in this area is imperfect and does not protect women's rights to political participation, thus limiting their access to political participation.

Despite quite substantial achievements in the field of legislative and regulatory support of gender equality in Ukraine, constant popularization of the fight against violence against women, and the use of international experience in combating gender inequality, the desired effect has not yet been achieved. The formation of gender policy is within the process of European integration development (Pishchulina, 2016). As for the constitutional and legal foundations of gender equality in the countries of the European Union, their formation begins with the EU creation and is one of its priorities. Analyzing the main documents of the European Union, it was found that each of them contains articles on non-discrimination, ensuring equality of rights of men and women, and standards of equality concerning men and women are part not only of the primary legislation but also of the acts issued by the European Union institutions (British council, 2017). The principle of gender equality is enshrined in the EU Directives, and nondiscrimination is considered a basic principle of individual rights and is enshrined in the Charter of Fundamental Rights of the European Union (EUR-Lex, 2012a).

In addition, Consolidated versions of the Treaty on the European Union and the Treaty on the Functioning of the European Union with protocols and declarations (EUR-Lex, 2012b) stipulate the equality of men and women and respect for their rights and freedoms. Among the main features of European legislation in the field of combating gender discrimination and affirming the principle of gender equality are: (1) the development of special measures to achieve equality between men and women, which aim to prohibit direct and indirect discrimination; (2) the prohibition of victimization, persecution and committing acts containing signs of sexual harassment; (3) the assignment of compensation and sanctions for violations of the law; (4) adopting specific legislation and regulations on gender equality; (5) introducing institutions to protect established rights (Chichkalo-Kondratska et al., 2019).

While appreciating the constitutional and legal foundations of gender equality in foreign countries, attention should be paid to the fact that the analysis of the Global Gender Gap Index in the European Union (Figure 3) has not had a steady upward trend. Some countries, in particular Austria, Belgium, Bulgaria, Ireland, Italy, Cyprus, Lithuania, Malta, the Netherlands, Germany, Portugal, Hungary, Finland, France, and the Czech Republic, have failed to achieve an increase in the value of this indicator, in Luxembourg, Slovenia and Sweden it has 
remained almost unchanged, while in Greece, Denmark, Estonia, Spain, Latvia, Poland, Romania, Slovakia, and Croatia, by contrast, it has significantly decreased compared to the previous year. This situation indicates that there are significant problems in ensuring equality of rights, freedoms, and opportunities for men and women.
At the same time, the international and national healthcare system caused by the COVID 2019 pandemic affected women more than men. According to the Global Gender Gap Report 2021 (World Economic Forum, 2021) estimates that $5 \%$ of all working women and $3.9 \%$ of men lost their jobs, deepening the gender gap in areas where parity had already been achieved.

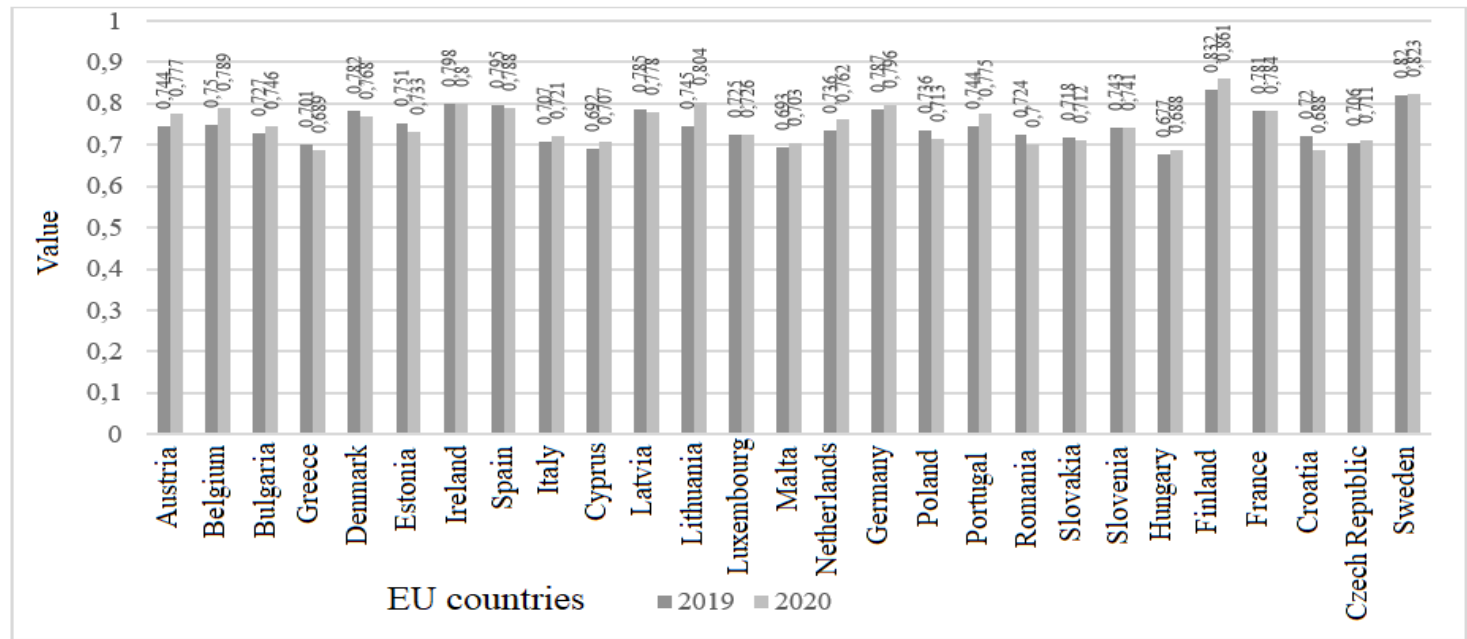

Figure 3. Global Gender Gap Index dynamics in the EU countries, 2019-2020

Source: Calculations based on The Global Gender Gap Report-2019, The Global Gender Gap Report 2020.

We consider it reasonable to compare the constitutional and legal framework of Ukraine and the EU countries. In addition, we assume that the legislation of Ukraine is partially implemented with the norms of international law in this area, and the presence of gender inequality to a greater or lesser extent exists in all countries. It is obvious that the society of post-Soviet countries is not aware of the gender inequality problem and perceives it as artificially traced from Western society.

To detail the research and confirm the hypothesis, we will cluster the EU countries and Ukraine according to the Global Gender Gap Index (Table 1).

Table 1.

Clustering the EU countries and Ukraine according to the Global Gender Gap Index in 2019 and 2020

\begin{tabular}{|c|c|c|c|c|c|}
\hline 2019 & & & 2020 & & \\
\hline Country & $\begin{array}{l}\text { Cluster } \\
\text { number }\end{array}$ & $\begin{array}{l}\text { Euclidean } \\
\text { space }\end{array}$ & Country & $\begin{array}{l}\text { Cluster } \\
\text { number }\end{array}$ & $\begin{array}{l}\text { Euclidean } \\
\text { space }\end{array}$ \\
\hline Denmark & & 0,037 & Austria & & 0,041 \\
\hline Ireland & & 0,002 & Belgium & & 0,020 \\
\hline Spain & & 0,031 & Ireland & & 0,004 \\
\hline Germany & 1 & 0,016 & Spain & & 0,022 \\
\hline Finland & & 0,043 & Lithuania & 1 & 0,056 \\
\hline France & & 0,028 & Germany & & 0,017 \\
\hline Sweden & & 0,032 & Finland & & 0,089 \\
\hline Austria & & 0,051 & France & & 0,028 \\
\hline Belgium & & 0,021 & Sweden & & 0,036 \\
\hline Estonia & & 0,007 & Bulgaria & & 0,031 \\
\hline Latvia & & 0,052 & Denmark & & 0,022 \\
\hline Lithuania & 2 & 0,046 & Italy & & 0,055 \\
\hline Netherlands & & 0,019 & Latvia & 2 & 0,047 \\
\hline Poland & & 0,019 & Netherlands & & 0,022 \\
\hline Portugal & & 0,007 & Portugal & & 0,032 \\
\hline Slovenia & & 0,051 & Croatia & & 0,032 \\
\hline
\end{tabular}




\begin{tabular}{llll}
\hline Bulgaria & 0,027 & Greece & 0,029 \\
Greece & 0,012 & Estonia & 0,030 \\
Italy & 0,058 & Cyprus & 0,009 \\
Cyprus & 0,033 & Luxembourg & 0,039 \\
Luxembourg & 0,023 & Malta & 0,027 \\
Malta & 0,029 & Poland & 0,003 \\
Romania & 3 & Romania & 0,037 \\
Slovakia & 0,025 & Slovakia & 0,013 \\
Hungary & 0,023 & Slovenia & 0,050 \\
Croatia & 0,061 & Hungary & 0,034 \\
Czech Republic & 0,023 & Czech Republic & 0,027 \\
Ukraine & 0,011 & Ukraine & 0,018 \\
\hline Source: Calculatia
\end{tabular}

Source: Calculated by the authors

The European Union countries are grouped into separate clusters. Each cluster has individual characteristics and features of socio-economic and political development. It's evidenced by the results of conducted assessments based on one of the methods of multidimensional statistical analysis (cluster analysis), which allows determining the relationship between the subindices of the Global Gender Gap Index.

The results of this research allow us to distinguish several groups of the EU countries, which have both common and distinctive features of gender equality.

Group 1. Highly developed countries, where the gender gap is minimal (Finland - 0,861; Sweden - 0,823; Germany - 0,796; Spain - 0,788; France - 0,784). In such countries, the level of constitutional and legal provision of gender equality is high, the level of women's access to participation in political, economic, and public life is rather high.

Group 2. The countries with a high level of socioeconomic development, where the gender gap tends to grow (Latvia - 0,778; Belgium - 0,777; Portugal - 0,775; the Netherlands - 0,762). However, the human rights system of this group of countries cannot sufficiently ensure gender equality and mitigate the problems of discrimination, sexism, and restrictions on women's right to participate in socio-political and economic life.

Group 3. The countries with a medium level of socio-economic development, where the gender gap is significantly lower (Hungary - 0,688; Greece - 0,689; Romania - 0,700; Malta - 0,703; Cyprus - 0,707; Czech Republic - 0,7 - 0; 0,726 and Ukraine - 0,714). The constitutional and legal framework of such countries was formed under the influence of remnants of the Soviet Union, is still incomplete, and requires harmonization and standardization. This group of countries is characterized by ignorance of the problem of gender inequality in society, the existence of gender stereotypes, frequent manifestations of violence against women, and significant restrictions on women's rights to participate in politics and economic life. The system of gender in the societies of these countries is often positioned as dichotomous and hierarchical, and the deepening of gender inequality is caused by empirically grounded and socially constructed social differences.

Let us note that in the conditions of 2019 , Ukraine was included in 3 clusters with such EU countries as Bulgaria, Greece, Italy, Cyprus, Luxembourg, Malta, Romania, Slovakia, Hungary, Croatia, and the Czech Republic. In 2020, the situation has slightly changed, and Ukraine, according to the results of the values of the analyzed indicator, is placed in the same 3 clusters with Greece, Estonia, Cyprus, Luxembourg, Malta, Poland, Romania, Slovakia, Slovenia, Hungary, and the Czech Republic, where is observed very slow progress. Based on the obtained data, we can state that Ukraine has a stable position among the post-Soviet countries with similar mental, socio-economic and geopolitical features. The constitutional and legal framework for gender equality in this group of countries is similar.

Regarding the study of EU countries in other clusters, it should be noted that Ireland $(0,800)$, Germany $(0,796)$, and Spain $(0,788)$ have quite a high value of the indicator. It is necessary to note that Sweden $(0,823)$ and Finland $(0,861)$ are considered to be the most gender-equal in the modern world.

Let us note the peculiarities of gender equality in Denmark, where the Global Gender Gap Index in 2020 , compared to 2019 , decreased significantly by 0,014 points from 0,782 to 0,768 . Denmark is considered as a country with a fairly high level of women's participation in political life and their representation in parliament, which is $37.4 \%$ (Gerbut, 2019). In comparison, in Ukraine, this 
indicator in 2019 was 20.5\% (Parline, 2019), in 2021 - 20.8\% (International Centre for Policy Studies, 2017), and in countries that have gender quotas average 26.2\% (Slovo i Dilo, 2020), which is two times less. At the same time, the Danish legislation does not provide special provisions for granting a specific number of electoral seats to women, i.e., there are no gender quotas. In Ukraine, the Constitution (Article 71) (Constitution of Ukraine, 1996) stipulates elections to state and local government bodies are free and take place by secret and equality-based ballot, as well as general and direct voting rights.

However, it should be noted that the largest asymmetries in the European Union countries and Ukraine are observed for the indicator of women's access to participation in political and economic life (Figure 4). At the same time, there is a positive trend of rights and opportunities equality in access to education and health care, which indicates the overcoming of the gender gap in these areas and rights equality between men and women.

In particular, in 2019, the most significant gap in terms of political participation was in the countries included in the third cluster, including Ukraine, and in 2020 the countries of the second cluster were affected by it. At the same time, in the countries of the third cluster, this gap was significantly reduced.

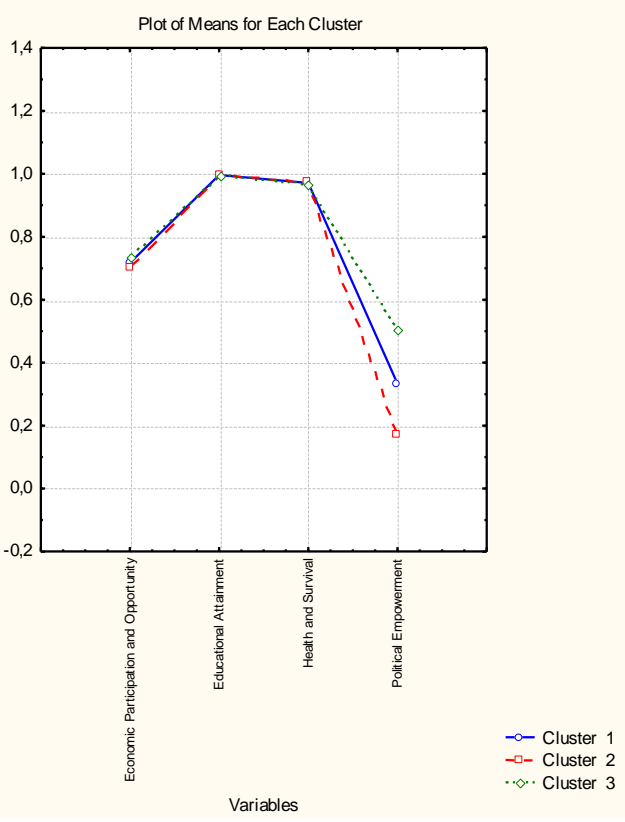

2020

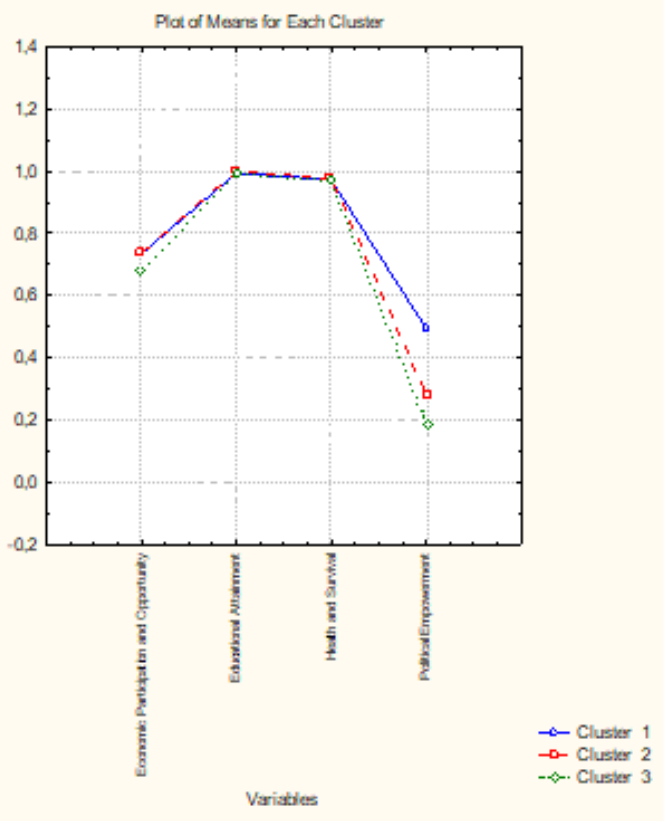

2019

Fig. 4. Differences between the EU countries and Ukraine on the Global Gender Gap Index sub-indices in 2019 and 2020

Source: Calculated by the authors

It should also be noted that the approval of the Concept of communication in the field of gender equality (Order № 1128-r, 2020) has increased women's access to more than 450 professions and positions, as well as eliminated discriminatory norms, including in the security and defense sector because the increasing role of women in peacekeeping and conflict prevention has been proven (Nikodinovska-Stefanovska, 2013). This normative legal act has somewhat weakened socially accepted stereotypes about women's role, place, and position in the labor market because the labor gender division is quite tangible (Tinker, 2019). There is a misconception that women are more demanding working conditions and less flexible to work overtime (Becker \& Gary, 2015). Furthermore, research proves that Germany is the most developed country in the European Union for women's participation in the security and defense sector, with about $10 \%$ of the total number of women serving in the armed forces (Vasilevski \& Pavlov, 2013).

It is necessary to draw attention to the issue of gender equality to prevent and counteract gender inequalities. The priority in this context is to inform women about their rights, freedoms, and opportunities. The second equally important task is to challenge stereotypes about women's roles 


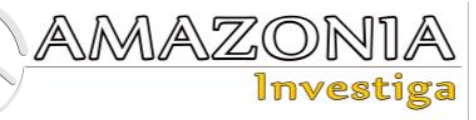

in society, economy, and politics (Ballington, 2008) and the need to cover up violations of women's rights to gender equality. Because the United Nations Convention on the Elimination of All Forms of Discrimination against Women (United Nations, 1979) proclaims the obligation to ensure the equal rights of men and women to enjoy socio-economic, cultural, social, and political rights, and makes any violence against them a crime.

\section{Conclusions}

The following tendencies, in the context of increasing globalization and European integration processes, highlight several problems in ensuring gender equality:

1. Increase of gender-based violence, which is more often demonstrated to the female gender. This type of violence includes domestic and sexual violence, including in the workplace.

2. Gender inequality in the labor market, which manifests itself in discrimination in the workplace. An obvious example is gender segregation, which provides for differences in wages for work in highpaying prestigious areas. It has been established that men occupy a dominant position in power, politics, and business, occupying the highest managerial positions, and, accordingly, the size of their pay is significantly higher than that of women.

3. Ensuring gender equality in politics, which indicates the level of democratization and civilization of society, and gender quotas, the practice of which in some countries of the European Union has proven its effectiveness, is a promising area for ensuring gender equality.

4. Bringing Ukrainian legislation into conformity with constitutional principles of equality and established European norms. In addition, criminal liability for committing acts of violence against women should be strengthened.

5. Introduction of gender innovations as a stimulus for improvement of scientific and technical developments based on gender integration (What is gender innovation?).

In conclusion, by having systematized scientific research in the sphere of constitutional and legal provision of gender equality in Ukraine and the European Union, we can assert that this issue attracts the attention of the world community and citizens of individual countries. Legal regulation in this sphere is at the stage of formation, development, and standardization at both the national and European levels. It has been established that to ensure gender equality in the countries it is not enough to establish the principle of gender equality based on constitutional and legal regulation. In this context, the need to form effective mechanisms for implementing gender equality standards and state policy to ensure it. The Constitution of Ukraine (1996) and the majority of basic laws of foreign countries enshrine the principle of rights' equality and opportunities for men and women, and subordinate regulatory legal acts detail them. However, the presence of significant stereotypes and non-recognition of the presence of the problem of gender inequality in society, restrictions on the rights, freedoms, and opportunities of women lead to the deformation of the mechanism to counter gender inequality and protect women's rights in the socio-political and economic life.

\section{Bibliographic references}

Ballington, J. (2008). Equality in Politics: A Survey of Women and Men in Parliaments. Inter-Parliamentary Union. Geneva, Switzerland.

Becker, G. (2015). Human Capital. Columbia University Press, 130-140. Available at: https://cup.columbia.edu/

British council (2017). Equality policy. https://www.britishcouncil.org/sites/default/f iles/2017-11-equality-policy.pdf.

Chichkalo-Kondratska, I.B., Derevyanko, A.K. \& Kondratska, D.S. (2019). Gender inequality in foreign countries: causes, features of development and state policy to overcome it. Problems of system approach in economy, 5(73), 41-46

Constitution of Ukraine (28 June, 1996) Verkhovna Rada of Ukraine, № 254k/96-VR. Available at: https://zakon.rada.gov.ua/laws/show/254\%D 0\%BA/96-\%D0\%B2\%D1\%80\#Text

Council of Europe (2018). Gender Equality Strategy for 2018-2023. Available at: https://rm.coe.int/prems-041318-gbr-genderequality-strategy-2023-ukrnew2/16808b35a4

Criminal Code of Ukraine № 2341-III. Verkhovna Rada of Ukraine of 5 April 2001. Available

at: https://zakon.rada.gov.ua/laws/show/234114\#Text

EUR-Lex (2012a). Charter of Fundamental Rights of the European Union. Available at: https://eur-lex.europa.eu/legal- 
content/EN/TXT/PDF/?uri=CELEX:12012P

$/ \mathrm{TXT} \&$ from $=\mathrm{SL}$

EUR-Lex (2012b). Consolidated versions of the Treaty on European Union and the Treaty on the Functioning of the European Union. Available at: https://eur-lex.europa.eu/legalcontent/EN/TXT/?uri=celex\%3A12012E\%2 FTXT

Fritsky, O.F. \& Romanyuk, I.I. (2017). Constitutional and legal aspects of ensuring gender equality in Ukraine. A young scientist, 5(1), 146-148. [In Ukraniano]

Gerbut, N. (2019). Women's participation in politics: the experience of Denmark. https://blog.liga.net/user/ngerbut/article/197 65

Hazel, R. (2000). Gender and Development: Concepts and Definitions. Brighton. https://www.greatagriculture.

org/resources/gender-and-development-

concept-and-definitions-prepared-

department-international

International Centre for Policy Studies (2017). Participation of Women in Ukrainian Politics,

http://icps.com.ua/assets/uploads/images/ima ges/eu/t_women_s_participation_in_the_ukr ainian_politics_eng.pdf

Law of Ukraine № 2866-IV. On ensuring equal rights and opportunities for women and men. Verkhovna Rada of Ukraine of 08 September $2005 . \quad$ Available at: https://zakon.rada.gov.ua/laws/show/286615\#Text

Law of Ukraine. № 5207-VI. On the Principles of Preventing and Combating Discrimination in Ukraine. Verkhovna Rada of Ukraine, 6 September 2012. Available at: https://zakon.rada.gov.ua/ laws/show/520717\#Text

Mohanty C.T. (1988). Under Western Eyes: Feminist Scholarship and Colonial Discourses. Feminist Review, 30, 61-68. Available at: https://journals.sagepub.com/doi/10.1057/fr. 1988.42

Nikodinovska-Stefanovska, S. (2013). Women in conflict and peace: contemporary gender perspectives. Contemporary Macedonian Defense. 13, 27-40.

Order № 1128-r. On the approval of the Concept of Communication on Gender Equality. Cabinet of Ministers of Ukraine dated 16 September 2020. Available at: https://zakon.rada.gov.ua/laws/show/11282020-\%D1\%80\#Text

Order № 229-r. The Concept of the State social program to ensure equal rights and opportunities for women and men for the period up to 2021. Cabinet of Ministers of Ukraine from 05 April 2017. Available at: https://www.kmu.gov.ua/npas/249890469

Parline (2019). Monthly ranking of women in national Parliaments. https://data.ipu.org/women-ranking? month $=10$ \&year $=2021$

Pishchulina, O.M. (2016). Gender equality and development: a view in the context of Ukraine's European strategy. Analytical report. K.: Publishing House «Testament».

Razavi, S. \& Miller, C. (1995). From WID to GAD: Conceptual Shifts in the Women and Development Discourse. The United Nations Research Institute for Social Development.

Slovo i Dilo (2020). How many female deputies in the parliaments of the world. https://www.slovoidilo.ua/2020/02/12/infogr afika/polityka/skilky-deputativ-zhinokparlamentax-svitu

Tinker, I. (2019). Women's Economic Roles and the Development Paradigm. University of California Berkeley. Available at: http://irenetinker.com/text-of-recentarticles/womens-economic-roles-and-thedevelopment-paradigm

United Nations (1979) Convention on the Elimination of All Forms of Discrimination against Women. Available at: https://www.un.org/womenwatch/daw/ceda w/text/econvention.htm

Vasilevski, G. \& Pavlov, F. (2013). Women involvement in creating and conducting defense and security policy in the world and in the Republic of Macedonia. Contemporary Macedonian Defense, 13, 93-106.

World Economic Forum (2017). The Global Gender Gap Report 2017. Available at: https://www.weforum.org/reports/theglobal-gender-gap-report-2017

World Economic Forum (2018). The Global Gender Gap Report 2018. Available at: https://www.weforum.org/reports/theglobal-gender-gap-report-2018

World Economic Forum (2019). The Global Gender Gap Report 2019. Available at: https://reports.weforum.org/global-gendergap-report-2019/

World Economic Forum (2020). The Global Gender Gap Report 2020. Available at: https://reports.weforum.org/global-gendergap-report-2020/

World Economic Forum (2021). The Global Gender Gap Report 2021. Available at: https://reports.weforum.org/global-gendergap-report-2021/ 